\title{
Posvećenje kroz spoznaju i oponašanje u Poslanici Filipljanima
}

\author{
Miroslav Balint-Feudvarski \\ Baptistička crkva Radosne vijesti, Nova Gradiška \\ mbalint.feudvarski@gmail.com
}

UDK:2.182:27-246

Izvorni znanstveni članak

Primljeno: 1, 2018.

Prihvaćeno: 3, 2018.

\section{Sažetak}

Kroz cijeli Novi zavjet nalazimo poticaje da oponašamo ili slijedimo primjer Krista, Pavla, pa čak i nekih drugih pobožnih ljudi. U Poslanici Filipljanima nalazimo taj poticaj da oponašamo, pripojen Pavlovoj teologiji progresivnog posvećenja. Posvećenje je u Filipljanima prikazano kao suobličavanje Kristu kroz spoznaju Njega, koja dolazi kroz trojni način Božje riječi (apostolskog učenja), unutarnjeg djelovanja Božjega Duha i oponašanja Krista, apostola Pavla i drugih pobožnih primjera. Pokušat ćemo oblikovati biblijsku teologiju posvećenja kroz oponašanje, ograničeni u svojoj analizi na Poslanicu Filipljanima. Prvi dio ovoga članka osvrće se na učenje o posvećenju u Filipljanima, s naglaskom na odlomke gdje Pavao izravno postavlja to pitanje: Filipljanima 1,9-11. 27-29; 2,12-16; 3,1-15. Drugi nas dio članka uvodi u biblijsko učenje o oponašanju, a zatim se osvrće na silaznu spiralu oponašanja: oponašanje Krista (Fil 2,5), oponašanje Pavla (Fil 3.17a; 4,9) i oponašanje Pavlovih vjernih oponašatelja (Fil 3,17b). U zaključku ćemo vidjeti da su oponašanje Krista $i$ Njegovih vjernih oponašatelja sredstvo progresivnog posvećenja, sredstvo koje je i važno i često zanemareno, kako od onih koji bi trebali služiti kao primarni primjeri pobožnosti (duhovni vođe) tako i od onih koji bi se trebali učiti oponašanju.

Ključne riječi: oponašanje, posvećenje, spoznaja, preobražavanje, primjer, Krist, Pavao, Filipljanima, Sveti Duh, Sveto pismo 


\section{Uvod}

Ljudska su bića stvorena da budu oponašatelji. Od najranije dobi uče ponašanje, govor, pa čak i stavove, oponašajući prvo svoje roditelje, braću i sestre, a zatim i druge ljude. Bog je stvorio ljude na svoju sliku, a to se najvjerojatnije odnosi na „ulogu čovjeka da vrši vlast nad ostatkom stvorenog poretka“" (Allison i Castaldo 2017, 77). Drugim riječima, ljudska bića trebaju oponašati Božju sveobuhvatnu vladavinu na Zemlji. Kada su pali u grijeh, nisu prestali biti oponašatelji. Naprotiv, njihov se kapacitet oponašanja samo povećao, tako da sada više nije uključivao dobre nego i loše primjere. Mojsije je bio svjestan toga kada je upozorio Izraelce: „Kad uđeš u zemlju koju ti daje Jahve, Bog tvoj, nemoj se priučavati na odvratne čine onih naroda" $(\mathrm{Pnz} 18,9) .{ }^{1} \mathrm{U}$ kulturi apostola Pavla i njegovih čitatelja, i židovski i grčki učenici „marili su za način života svoga učitelja, kojega su obično željeli oponašati“ i stoga su htjeli „sačuvati djela i karakter svojih učitelja zajedno s njihovim učenjem" (Keener 2009, 32). Da se od učenika očekivalo da oponašaju svoje učitelje, jasno je čak i iz Kristova negativnog komentara: „Vršite i držite sve što vam (književnici i farizeji) reknu, ali se ne ravnajte po njihovim djelima, jer govore, a ne vrše“ (Mt 23,3).

Sveto pismo Isusa naziva „savršenom slikom Boga nevidljivoga“ (Kol 1,15), a on je sam rekao da oponaša svoga Oca (Iv 5,19). To je zanimljivo u svjetlu svetopisamskog učenja, da je cilj kršćanskog života doista cilj spasenja, biti prilagođen slici Isusa Krista (Ef 4,24; Rim 8,29; 1 Iv 3,2). Stoga, ne treba nas čuditi da Sveto pismo proširuje ovaj prikaz oponašanja od oponašanja Krista do oponašanja i drugih pobožnih primjera. Jedan od najopsežnijih poziva na oponašanje nalazimo u Poslanici Filipljanima. Ovaj će članak pokušati istražiti učenje Poslanice o vjernikovu posvećenju, a zatim i povezanost koja postoji između posvećenja i poticaja na oponašanje Krista, Pavla, ali i drugih vjernika.

\section{Posvećenje u Filipljanima}

U Pavlovim spisima posvećenje se može podijeliti na tri različite, ali međusobno povezane ideje. Thomas Schreiner je istaknuo da, premda „često posvećenje razumijemo samo u smislu progresivnog rasta u kršćanskom životu“, „Pavao obično ističe Božje definitivno djelo stavljanja na stranu pri obraćenju“, na primjer u 1. Korinćanima 1,2, gdje Korinćane naziva „posvećenima u Kristu“ (Schreiner 2008, 372-3). Pavao također istu riječ koristi za „neprekidno djelo svetosti u ži-

1 Svi navodi iz Biblije preuzeti su iz Biblije: Stari i Novi zavjet. Kršćanska sadašnjost, Zagreb, 2006., osim ako je drukčije naznačeno. 
votima vjernika“ (Schreiner 2008, 374). Na kraju, posvećenje je, prema Pavlu, ujedno i eshatološka stvarnost budući da uključuje konzumaciju svetosti, kada će vjerne „Bog u potpunosti posvetiti“ (1 Sol 5,24) (Schreiner 2008, 375). Pavlov nauk o posvećenju slijedi onu „već, ali ne još dimenziju Pavlove eshatologije“ (Schreiner 2008, 375). Znači da su u Pavlovoj misli međusobno povezane te tri ideje o posvećenju. Vidjet ćemo kako se to odigrava u njegovoj Poslanici Filipljanima.

\section{Bog je začetnik i dovršitelj eshatološkog posvećenja}

Na samome početku svoje poslanice Pavao je vrhovni razlog za zahvalnost Bogu za Filipljane pronašao u svome uvjerenju da će Bog usavršiti ili dovršiti dobro djelo koje je započeo u njima ili među njima (O’Brien 1991, 63). Mnogi tumači slažu se da je to dobro djelo vezano uz njihovo spasenje (Calvin 2010, 26) ili, pobliže, posvećenje (v. Witherington 2011, 60; Spurgeon 2014, 11) premda ne misli svatko da je to dobro djelo soteriološke naravi. ${ }^{2}$ Peter O'Brien u ovome stihu vidi aluziju na Postanak 1. i 2. poglavlje, gdje je Božje djelo opisano kao dobro. Smatra da Pavao također aludira na Knjigu proroka Izaije, gdje je Bog nazvan prvi $i$ posljednji (Iz 41,4; 44,6; 48,12), u svome djelovanju kao stvoritelj Izraela (O’Brien 1991, 64-65). Prema tomu, Pavao poučava da je Bog začetnik i dovršitelj vjernikova spasenja, ${ }^{3}$ a neki tumači ističu čak i progresivnu narav dovršavanja toga

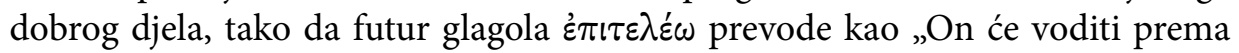
dovršenju te će ga na kraju dovršiti. " 4 U svakom slučaju, progresivna ideja se podrazumijeva. U slučaju da je O’Brien u pravu i da Pavao aludira na Postanak 1. i 2. poglavlje, ${ }^{5}$ možemo zaključiti da je posvećenje sastavni dio postupka preobrazbe $\mathrm{u}$,novoga čovjeka, stvorena na sliku Božju u istinskoj pravednosti i svetosti“ (Ef $4,24)$.

Preobrazba se neće okončati ni prije ni poslije, nego na Dan Krista Isusa (Fil 1,6). Ovu ćemo istinu vidjeti ponovno u Filipljanima 3, gdje Pavao kaže da svi

2 Neki smatraju da Pavao ovdje govori o nekom specifičnom djelu koje Bog čini u Crkvi u Filipima (Foulkes 1994, 1250) ili da će Bog postići misiju naviještanja evanđelja u Filipima dok se Krist ne vrati (Lightfoot 1981, 84). Međutim, sudjelovanje Filipljana u naviještanju evanđelja bolje je vidjeti kao plod Božjeg djelovanja u njima nego kao sredstvom do nekoga cilja (O’Brien 1991, 64).

3 Vidi Heb 12,2, gdje za Gospodina Isusa piše da je „začetnik i završitelj vjere“.

4 Rogers 1998, 448; Hendriksen 1964, 54; nasuprot Wallaceu: „Budući da se nalazi između proš-

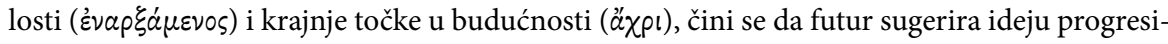
je. Međutim, futur sam po sebi ništa od toga ne naznačuje“ (Wallace 1996, 568).

5 Tu aluziju nisu primijetili tumači u djelu Commentary on the New Testament Use of the Old Testament. 
koji su savršeni ${ }^{6}$ znaju da još uvijek nisu savršeni, odnosno da još nisu dosegli stanje savršene pravednosti i svetosti. Pavao je upotrijebio nekoliko izraza da opiše takvo stanje. U Filipljanima 3,11 naziva ga uskrsnuće od mrtvih, u 3,12 ga povezuje s postignućem savršenstva. U 3,14, Pavao trči prema cilju da postigne nebesko stanje u koje nas je Bog pozvao po Kristu Isusu. Ovdje imamo zanimljiv primjer teološke napetosti, između Pavlova truda da postigne nebesko stanje, savršenstvo ili uskrsnuće od mrtvih (što se može usporediti s trudom trkača da osvoji nagradu) te jasnog učenja da on to stanje neće moći postići prije Kristova povratka. Zbilja, riječ je o nebeskom stanju, a u Filipljanima 3,18-19 Pavao ispravlja one koji možda misle da su već postigli savršenstvo, vjerojatno one koji se pouzdaju u tijelo i zadovoljni su svojim trenutnim ovozemaljskim stanjem. ${ }^{7}$ Nakon ovoga upozorenja, Pavao je gotovo pobjegao u doksologiju u 3,20-21:

„A naša je domovina na nebesima, odakle i Spasitelja postojano očekujemo, Gospodina Isusa Krista, koji će, prema djelotvornosti kojom može sve podložiti sebi, preobraziti naše bijedno tijelo i učiniti ga jednakim svome slavnom tijelu."

Ralph Martin tvrdi da Pavao ovdje aludira na dvostruko građanstvo u kojem su uživali građani Filipa, koji su sebe prije svega smatrali građanima Rima koji žive u rimskoj koloniji u Filipima (Martin 1991, 129). Pavao sigurno nije jedini koji je opisao domovinu kršćana na nebu. ${ }^{8}$ Rimsko građanstvo Filipljanâ je, u svakom slučaju, dobra ilustracija već, ali ne još tenzije vjernikova života. Vjernik je već građanin neba, ali živi na Zemlji u onome što Pavao naziva naše bijedno tijelo (s. 21). Pavao ovdje opisuje ono što drugdje naziva proslavljenjem ${ }^{9}$, kao preobražaj našega bijednog tijela, te kaže da će ga Krist učiniti jednakim svome slavnom ti-

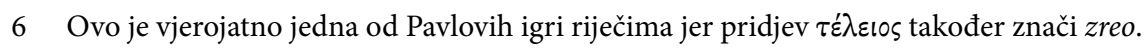

7 Pavao ovdje ne elaborira o teologiji onih koji misle da su postigli savršenstvo. Pretpostavljam da je njegova kritika upućena onima na koje je upozorio Filipljane početkom 3. poglavlja. Međutim, zanimljivo je usporediti to s komentarima Gordona Feea u njegovu komentaru na Prvu poslanicu Korinćanima, u kojima opisuje devijantnu korinćansku teologiju kao „previše realizirano gledište o njihovu sadašnjem postojanju“, nazivajući je „produhovljenom eshatologijom“ (Fee 1987, 12). Fee piše da su oni koji su u Korintu imali produhovljenu eshatologiju „smatrali da su već postigli 'uskrsnuće od mrtvih' tako što su u duhu i stoga već poput anđela“ (Fee 1987, 269), da su zato „zanemarivali neke poprilično uvriježene razlike između spolova“ (Fee 1987, 498) te "nijekali vrijednost / značaj tijela“ (Fee 1987, 716). Također, prezirali su Pavla „čije su slabosti učinile očitim da on još nije stigao“ (Fee 1987, 12).

8 Vidi Heb 11,16, gdje vjernici uzdišu za svojom nebeskom domovinom, a grad koji im je Bog pripravio u Otk 21,2 silazi s neba da počine na Novoj Zemlji.

9 U svome komentaru na Poslanicu Rimljanima, Douglas Moo ističe da je ovaj odlomak paralelan s Rimljanima 8,28-30, gdje je Božja glavna svrha u predodređenju, naime, da se vjernici prilagode slici Njegova Sina, naziva proslavljenjem (Moo 1996, 535). 
jelu. U 2. Korinćanima 11,13-15, glagol $\mu \varepsilon \tau \alpha \sigma \chi \eta \mu \alpha \tau i \zeta \omega$ opisuje Sotonino lukavo pretvaranje $u$ anđela svjetla, kao i pretvaranje lažnih učitelja u Kristove apostole,

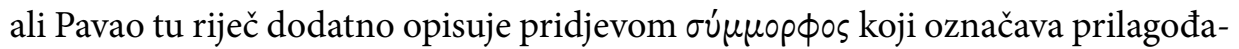
vanje ili izjednačavanje s Kristovim proslavljenim tijelom.

\section{Bog je začetnik i ostvaritelj progresivnog posvećenja}

Prema tomu, vidjeli smo da vjernicima pripada nada konačnog posvećenja (proslavljenja), kada njihova bijedna tijela ${ }^{10}$ postanu jednaka Kristovom slavnom tijelu u svoj njegovoj moralnoj ljepoti i savršenoj svetosti. Vidjeli smo uvjerljivo tumačenje Filipljanima 1,6, prema kojem je Pavao vjerovao da Bog nije samo započeo dobro djelo spasenja među Filipljanima s njihovim definitivnim posvećenjem, posvećenjem koje će se okončati kada se Krist vrati da ih konačno prilagodi samome sebi, nego da je bio siguran i u njihovo progresivno posvećenje. De facto, njihovo kontinuirano posvećenje, koje se očitovalo u sudjelovanju širenja Evanđelja $(1,5.7 ; 2,30 ; 4,3)$, njihovoj poslušnosti Pavlu $(2,13)$, pa čak i njihovim financijskim darovima u svrhu Pavlove službe (4,10-19), postaje temelj njegove sigurnosti $(1,6)$ da Bog djeluje u njihovu životu. ${ }^{11}$

Unatoč tomu, crkva u Filipima nipošto nije bila idealna. Iznutra, nije bila ujedinjena, zbog čega Pavao naglašava jedinstvo, slogu i poniznost $(1,27 ; 2,1-4$; 4,2-3). Takvo jedinstvo i poniznost obilježja su Crkve koja se ponaša „dostojno Kristove Radosne vijesti“ $(1,27)$, koja radi oko svoga spasenja $(2,12)$ te u kojoj je Bog aktivan u njihovu posvećenju $(2,13)$. Pavao ih potiče da se tako ujedinjeni bore za „vjeru Radosne vijesti“ $(1,27 ; 2,16)$. Takva razjedinjenost i suparništvo u crkvi čine ju ranjivom na napade izvana. Pavlovo ohrabrivanje na posvećenje s njegovim opisom, dolaze im u kontekstu toga unutarnjeg suparništva i napada izvana.

Usredotočit ćemo se na određene odlomke u kojima Pavao govori o progresivnom posvećenju, s posebnim naglaskom na Božji poticaj i na spoznaju Krista u posvećenju.

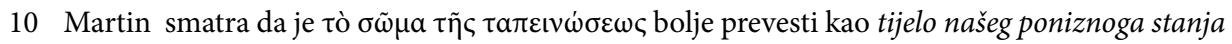
(slično Šarić „tijelo poniznosti naše“ i Dretar "naše poniženo tijelo“, a ne naše bijedno tijelo, jer onda možemo vidjeti vezu s Kristovom poniznošću u Fil 2,8 (Martin 1991, 131). Implikacije takve povezanosti su bogate i igraju sličnu ulogu kao Pavlovo korištenje 2 Kor 8,9 u ohrabrenju Korinćana da budu darežljivi prema siromašnim vjernicima u Judeji: „Ta, poznato vam je milosrđe Gospodina našega Isusa Krista, kako je radi vas od bogataša postao siromah, da vi postanete bogataši njegovim siromaštvom."

11 Sličnu sigurnost nalazimo u 1 Sol 1,4-10, gdje pokajanje i služenje Solunjana Bogu pokazuju Pavlu da ih je izabrao Bog. 


\section{Pavao se moli za njihov rast u spoznaji (Fil 1,9-11)}

U ovome odlomku Pavao moli za Filipljane, tako da svjedočimo njegovoj brizi i dubokom razumijevanju duhovnih potreba njegovih prijatelja. Razmišlja o njima, razumije njihove probleme i moli se za njih. To su definitivno potrebe za molitvu koje možemo ponijeti sa sobom na sljedeći molitveni sastanak jer su istovremeno usklađene s Božjom voljom.

Budući da Pavao ne kori ni jednu frakciju u Filipima za nekakav upadljiv grijeh ili krivovjerje, ${ }^{12}$ možemo zaključiti da su nesuglasice između vjernika u ovome gradu bile osobne naravi ili pak osobnih želja. Pavao spominje nadglednike i pomoćnike (đakone) u svome pozdravu, što ne čini u drugim kanonskim poslanicama. Moguće je da su nadglednici i đakoni obavijestili Pavla o problemu sukoba u crkvi, a to bi značilo da Poslanica ujedno služi kao tihi poticaj crkvi da se predaju njihovu privrženom autoritetu? ${ }^{13}$

Pavao moli da njihova ljubav sve više obiluje u pravoj ili potpunoj spoznaji i svom rasuđivanju. Prava spoznaja ${ }^{14}$ nema nikakav objekt, ali možemo zaključiti, iz uobičajene uporabe te riječi u drugim Pavlovim poslanicama i iz konteksta ove poslanice (Fil 3,8) da govori o pravoj i rastućoj spoznaji Boga kroz Krista. Svako rasuđivanje odnosi se na „sposobnost donošenja moralnih odluka usred mnoštva različitih i teških izbora" (Rogers Jr. i Rogers III 1998, 449). Takva spoznaja i takvo rasuđivanje, koji informiraju i izgrađuju ljubav, pomoći će im da rasude što je bolje. Drugim riječima, svojim odlukama i djelima pokazat će se iskrenim i besprijekornim na Kristov Dan, a njihov plod pravednosti, koji dolazi kroz Isusa Krista, ${ }^{15}$ donijet će čast i slavu Bogu.

\section{Pavao ih ohrabruje da žive dostojno Kristove Radosne vijesti (Fil 1,27-29)}

Ovaj odlomak počinje uputom da se Filipljani trebaju ponašati na način koji

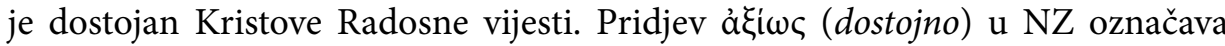
prilagođavanje nečijeg ponašanja određenu mjerilu koje je postavljeno kao pri-

12 Prema svemu sudeći, judaisti u Fil 3,1-15 nisu bili članovi Crkve u Filipima, a neki komentatori vjeruju da su u to vrijeme bili samo potencijalna prijetnja te da „još uvijek nisu ozbiljno ušli u život zajednice“" (O’Brien 1991, 354).

13 Vjerojatno nije slučajnost da u himni Carmen Christi (Fil 2,6-11) Krist postaje primjerom ponizne podložnosti autoritetu, unatoč Njegovoj jednakosti s Bogom, a stoga i unatoč njihovoj kršćanskoj jednakosti. Pavao im daje još jedan poticaj na podložnost u Fil 2,12, kao i poticaj da sve čine „bez mrmljanja i oklijevanja“ (s. 14). Isto tako, postoji barem mogućnost da je Pavlov „vjerni drug” u Fil 4,3, koji je trebao pomoći Evodiji i Sintihi prilikom pomirbe, bio jedan od nadglednika crkve (Witherington III 2011, 237). Prema tomu, vrlo je vjerojatno da su, između ostalih, upravo ti nadglednici i đakoni oni koji „žive prema primjeru što vam ga mi dajemo“ (Fil 3,17) i oni čiji je primjer Pavao htio da Filipljani slijede.

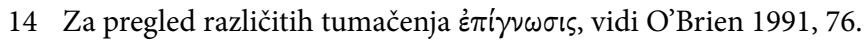

15 Usp. Fil 3,9 s Gal 5,22-26, kao i s poticajima koje nalazimo u Fil 2,1-4. 
mjer. ${ }^{16}$ Mjerilo je Kristova Radosna vijest, koja odražava njegovu narav i volju. ${ }^{17}$ Živjeti dostojno Kristove Radosne vijesti znači ponašati se u skladu s njegovim primjerom, koji Pavao opisuje u Filipljanima 2,6-9, ali i u skladu s povlasticama koje je Isus postigao za nas kroz svoj život, smrt i uskrsnuće (Fil 3,10; usp. Gal 2,19-20). Pavao naglašava jedinstvo Filipljana s Kristom u njegovim patnjama, dok ,stojite čvrsto u jednome duhu, da se ujedinjeni jednodušno borite za vjeru Radosne vijesti“ (1,27). Oni su također sjedinjeni s Pavlom vodeći istu borbu (s. 30). Trebali bismo zapaziti da Pavao u istoj poslanici ohrabruje vjernike da se bore za evanđelje i potiče ih da budu ponizni $(2,3)$ i ljubazni $(4,8)$. To nas podsjeća na Isusa, koji je uvijek bio ljubazan prema svojim slušateljima, čak i onda kada je djelovao odvažno i izravno. ${ }^{18}$ Biti ponizan i milostiv ne znači razvodniti istinu, nego je govoriti u ljubavi (Ef 4,15).

\section{Pavao potiče Filipljane da se trude oko ${ }^{19}$ svoga spasenja (Fil 2,12-16)}

Nakon što ih je potaknuo da budu jedinstveni i ponizni (2,1-4) i nakon Kristova izvrsnog primjera ponizne podložnosti i uzvišenja koje je iz nje proizašlo (2,5-11), apostol svoje čitatelje u retku 12 potiče da se trude oko svoga spasenja „sa strahom i drhtanjem“. Uviđamo nekoliko zanimljivosti. Kao prvo, rad oko spasenja sa strahom $i$ drhtanjem čini se kao da se suprotstavlja Pavlovoj sigurnosti u 1,6, da će Bog dovršiti svoje dobro djelo koje je započeo u vjernicima. U najmanju ruku, kršćaninova sigurnost ne znači da on neće raditi na svome posvećenju. Autor Poslanice Hebrejima upozorio je vjernike da teže za „posvećenjem bez kojega nitko neće vidjeti Gospodina" (Heb 12,14). Pavlov izraz sa strahom i drhtanjem ne treba značiti da ih Pavao potiče na nezdrav strah od Boga, da drhte oko mogućnosti svoje vječne propasti ili da se boje da će ih Bog odbaciti. Naprotiv,

16 Rim 16,2: kako dolikuje svetima; Ef 4,1: dostojno poziva kojim ste pozvani; Kol 1,10: dostojno Gospodina; 1. Sol 2,12: dostojno Boga; 3. Iv 6: dostojno Boga; i ovdje.

17 Usporedi Mt 11,28-30, gdje nas Isus poziva da učimo od Njegove krotkosti i poniznosti. Njegovo učenje odražava Njegovu narav. Također, Rim 6,17 gdje je, prema Georgeu Zemeku, „novo učenje, tj. poruka o Kristu, čimbenik koji zapečaćuje i određuje kršćaninov život“" (Zemek 2002, 254).

18 John Crotts dobro objašnjava te trenutke kada se nije činilo da je Isus bio ljubazan prema ljudima: „Kada je Isusova komunikacija s drugima bila intenzivna, On nikada nije bio grješno srdit. Naprotiv, uvijek je bio motiviran obranom i obznanjivanjem Božje slave. Kada bi Isusa osobno napali, bio je ljubazan, čak i kada su ga grdili na križu, ali kada su dovodili u pitanje Božju slavu ili Njegove božanske naume u Njegovoj misiji Mesije, odgovarao bi odvažno“" (Crotts 2018, Kindle loc. 534).

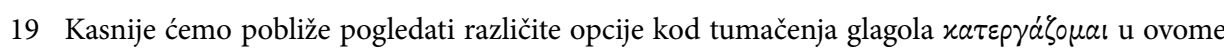
stihu. Ovdje slijedimo prijevod Dude-Fućka zbog njegove neutralnosti. Međutim, drugi prijevodi isti glagol prevode: „postići“ (Biblija KS), „raditi oko“ (Jeruzalemska Biblija), „raditi o“ (Šarić), „ostvarivati“ (Dretar), „graditi“ (Daničić-Karadžić) i „raditi oko“ (Varaždinska Biblija). 
potiče ih na „stav dužnog poštovanja i divljenja u Božjem prisustvu, pobožnog straha vjernika u pogledu posljednjeg dana“ (O’Brien 1991, 238). ${ }^{20}$ Također, moguće je da je Pavao htio stvoriti kontrast u svome poticaju Filipljanima da se ne smiju bojati svojih protivnika, ${ }^{21}$ nego da trebaju imati zdrav strah i divljenje pred Gospodinom, strah koji poništava svaki strah od ljudi (vidi Welch 1997, 95-134). Još bolje, u pogledu Izaije 6,5-7, mogli bismo reći da je taj strah $i$ drhtanje zapravo prva i spontana reakcija na Božju svetost, prije nego što uzmemo u obzir oproštenje koje nam je pribavljeno. Kao da Pismo želi reći da vjernici nikada ne bi smjeli izgubiti taj strah $i$ drhtanje, ali i da, s obzirom na spasenje, nikada ne smiju u njima predugo ostati (vidi 1 Iv 4,17-18). U svakom slučaju, ovaj izraz znači da bi svaki kršćanin trebao svome spasenju pristupati ozbiljno (vidi Gal 6,7 i dalje).

Drugo, truditi se oko spasenja sa strahom i drhtanjem treba se protumačiti u svjetlu Pavlove sigurnosti koju je izrazio u sljedećem stihu: „Bog je, naime, onaj koji proizvodi u vama i htjeti i djelovati iz svoje dobrohotnosti“ (redak 13; Duda-Fućak). Drugim riječima, Bog koji je „započeo dobro djelo u vama“ i koji će ga „dovršiti do Dana Krista Isusa“ $(1,6)$, ujedno „proizvodi u vama“ $(2,13)$. Umetanje straha i drhtanja u ovu jednadžbu, po svemu sudeći, spašava nas od duhovne letargije i tromosti, a $u$ isto vrijeme obeshrabruje našu samodostatnost i nezdravu opsjednutost vlastitim spasenjem. Štoviše, potiče nas da svoju vjeru i sigurnost polažemo u Boga te da se u pogledu spasenja pouzdajemo isključivo u Krista, istovremeno surađujući s Božjim Duhom u svakodnevnom posvećenju i služenju. ${ }^{22}$

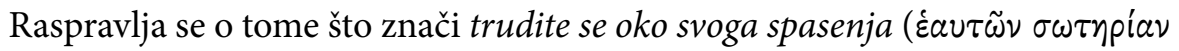

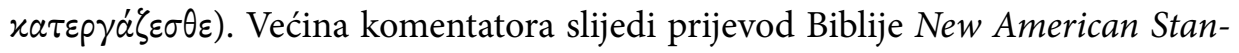
dard Bible „work out" (izraditi, razraditi, ostvariti), ističući značenje „provesti do cilja, dovesti do krajnjeg dovršetka ... kristosličnosti“ (Wuest 1997, Fil 2,12). S

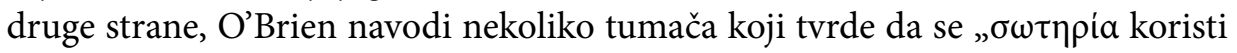
$\mathrm{u}$ sociološkom, a ne u strogom teološkom smislu, kako bi se opisalo duhovno zdravlje i dobrobit cijele zajednice u Filipima" (O’Brien 1991, 277). Međutim, on odbacuje ta gledišta i iznosi svoje prema kojemu Pavao „nagovara Filipljane da očituju Kristove milosti u svojim životima, da svoje vječno spasenje učine plodonosnim u ovome životu dok ispunjavaju svoje odgovornosti kako jedni prema drugima, tako i prema nekršćanima“ (O’Brien 1991, 280). Ben Witherington se

20

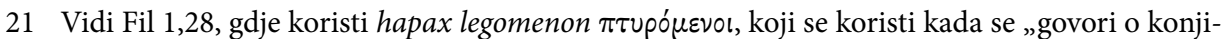
ma ili drugim životinjama koje su iznenada zapanjene ili uplašene“ (Jamieson, Fausset i Brown 1997, 362).

22 Djelovanje Duha kao Božjega vršitelja posvećenja vidimo u ovim i drugim stihovima: 2 Kor 3,18; Gal 3,5; Ef 3,16; 1 Pt 1,2. 
slaže s O’Brienom da Pavao govori o teološkom spasenju, ali se njegovo gledište razlikuje od O'Brienovog u tome što smatra da Pavao „govori o zajednici u kojoj jedni drugima pomažu da ostvaruju svoje osobno spasenje“" (Witherington III 2011, 159).

Thomas Schreiner, s druge strane, ide dalje i parafrazira zapovijed kao postići svoje vlastito spasenje te tvrdi da "taj glagol jednostavno znači 'raditi, postići' ili “činiti"“ (Schreiner 2001, 256). Međutim, objašnjava da „taj poziv na postizanje spasenja ne podliježe pravednosti iz djela, niti uzdiže ljudsku autonomiju“ budući da njihovoj „poslušnosti... snagu daje Bog“ (Schreiner 2008, 657). Razlikuje pravedno ponašanje koje „premda nije temelj spasenja - u potpunosti je nužno za postizanje spasenja“ (Schreiner 2001, 226). Dakle, tvrdi da vjernici postižu svoje spasenje, ali ne "zaslužuju svoje spasenje“ jer su „njihovi grijesi već oprošteni“ (Schreiner 2001, 257). Prema tomu, čini se da najizglednija dva gledišta, ona koja zagovaraju Schreiner i O’Brien, raspravljaju trebamo li se truditi oko našeg spasenja ostvarujući naše posvećenje (Schreiner) ili truditi se oko našeg posvećenja $i$ time ostvariti naše spasenje (O’Brien). Čini se da oba tumačenja stavljaju velik naglasak i na Božjoj snazi koja postiže posvećujuće djelo u vjernicima i na odgovornosti vjernika da aktivno sudjeluju. U svjetlu toga, možemo izvesti zaključak da Pavao potiče vjernike da se trude oko svoga progresivnog posvećenja imajući u vidu svoje eshatološko posvećenje kao cilj prema kojemu trebaju stremiti.

Ne smijemo previdjeti važnu vezu toga truda oko spasenja i poslušnosti Pavlu kao njihovu duhovnom vođi. ${ }^{23}$ Našu poslušnost Bogu ne možemo lišiti autoritativnog Božjega glasa koji nalazimo u Pismu, koje su napisali Njegovi apostoli $i$ proroci (Ef 2,20; 2 Sol 3,14), ali ni od podložnosti pobožnom autoritetu naših vođa (Heb 13,17), starijim kršćanima (1 Pt 5,5) i općenito jedni drugima (Ef $5,21)$. Smatram da sa sigurnošću možemo zaključiti da je Pavao takvu poslušnost smatrao još jednim sredstvom posvećenja.

\section{Pavao opisuje posvećenje kao rast u spoznaji Krista (Fil 3,1-15)}

Ovaj odlomak počinje imperativom koji često susrećemo u ovoj Poslanici: „Radujte se u Gospodinu!“ Ohrabruje vjernike da se raduju unatoč svojim okolnostima, naime, zatočeništvo njihova duhovnog oca (Fil 2,12. 17-19), njihove svakodnevne potrebe i prepirke $(4,4)$, suočavanje s protivnicima Radosne vijesti $(3,1$ $i$ dalje), kao i zastoji u njihovu posvećenju (3,12-13). Pavao upozorava Filipljane na judaiste, koji su zagovarali da se vjernici obraćeni s poganstva trebaju obrezati i biti poslušni Mojsijevu Zakonu (Gal 5,2-10). U Galaćanima 6,14, Pavao kršćane naziva Božjim Izraelom, a u Filipljanima 3,3 naziva ih obrezanjem i suprotstavlja

23 Schreiner je to istaknuo u komentaru koji je napisao u osvrtu na jednu moju radnju, napisanu za njegov predmet Teologija Novoga zavjeta 2010. godine. 
ih krivoobrezanima (3,2; Duda-Fućak: uškopljenici; Jeruzalemska Biblija: osakaćenost). Pavao ističe dva obilježja pravih kršćana. Prvo, njihovo je štovanje pota-

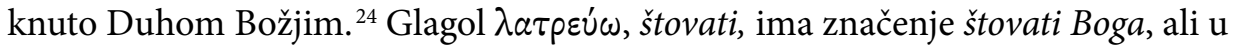
ovome stihu čini se da ga Pavao koristi kao sinonim za život posvećenja (vidi Rim 12,1-2; Heb 9,9. 14; 12,28). Nadalje, pravi vjernici ponose se Kristom Isusom i ne stavljaju svoga pouzdanja u tijelo. U Filipljanima 3,4-6, Pavao iznosi argumente po ludosti (Izr 26,5), uspoređujući sebe s bilo kime tko se želi pouzdati u tijelo. Važno je shvatiti da Pavao ne kaže da bi se on zbilja mogao pouzdati u tijelo u pogledu spasenja (vidi Gal 2,15-16), nego da može biti „sparing“ partner bilo kome tko bi htio tako nešto pokušati.

Spoznaja Krista Isusa, u 3,7-8, označena je kao ono najizvrsnije (Jeruzalemska Biblija). Ta mu je spoznaja bila toliko vrijedna da je sve smatrao gubitkom i sve žrtvovao „da Krista dobijem i da budem u njemu“ (redak 8). Pavao ovdje govori o cijeni učeništva koju je spreman platiti, a ne o nekakvim zaslugama prema kojima čovjek dolazi Kristu budući da dodaje: „ne pravednošću koja bi bila moja - onom koja dolazi od Zakona - nego koja se dobiva po vjeri u Krista, pravednošću koja dolazi od Boga na osnovi vjere" (redak 9). Ta je spoznaja Krista Isusa sveobuhvatna jer obuhvaća Njega samoga i silu Njegova uskrsnuća, zajedništvo u Njegovim patnjama i prilagođavanje Njegovoj smrti. Pavao svojim čitateljima daje primjer istoga stava, koji je vidio u Isusu, stava poniznosti i samopožrtvovnosti (vidi Fil 2,5 i dalje). Drugim riječima, Pavao uči od Krista i smatra druge većima od sebe žrtvujući svoj život za njih u poslušnosti Gospodinu. ${ }^{25}$ Sve to čini „ne bih li kako

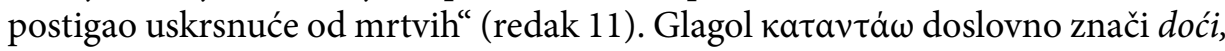
stići ili postići neko stanje postojanja (Swanson 1997, GGK2918) i ne znači zaslužiti. Pavao nadalje opisuje to stanje kao (biti) savršen $^{26}$ (redak 12) i kao nagrada - nebesko stanje (redak 14). Pavao koristi isti glagol u 1. Korinćanima 9,24 za nagradu koja se daje pobjedniku na natjecanju u trčanju. U 2. Timoteju 4,7 dovršena utrka znači sačuvati vjeru do kraja. U Hebrejima 12,1-3, autor govori o utrci u kojoj treba odbaciti svako breme i grijeh. Ponovno, naš je primjer u toj utrci sam Gospodin Isus, koji je začetnik i dovršitelj vjere, koji je pretrpio križ i takvo protivljenje grješnika protiv sebe.

Prema tomu, Pavao daje primjer težnje da pretoči tu spoznaju Krista u praksu (Fil 3,8), kroz duhovno prilagođavanje slici Gospodinovoj (usp. 2 Kor 3,18). On sam je težio da sve više prilagođava svoj život ovdje na Zemlji stanju savršenstva

24 Imenica $\pi \nu \varepsilon u ́ \mu a \tau ı$ može biti instrumental, koji bi značio štovanje Duhom ili štovanje potaknuto Duhom. Vidi Wallace 1996, 158-171.

25 Vidi Fil 2,17, gdje Pavao kaže da se žrtvuje za njihovu vjeru. Također, Djela 9,16, gdje je Pavao trebao trpjeti zbog Kristova imena.

Vidi Lk 13,32, gdje Isus povezuje uskrsnuće s postajanjem savršenim. 
koje ga čeka nakon uskrsnuća. Ipak, Pavao je stajao čvrsto na tlu jer je znao da neće moći dostići to stanje za vrijeme ovoga života (Fil 3,12-13. 15-16). Međutim, to ga nije obeshrabrilo da nastavi težiti i napredovati.

U zaključku, možemo reći da je Pavao jasno poučavao Filipljane da je posvećenje progresivan preobražaj u Kristovu sliku, do kojega dolazi spoznajom Krista i uz poticaj Božjega Duha. Progresivno je posvećenje stvarnost u kojoj vjernici već uživaju, u nadi u buduće proslavljenje, koje još nije njihova stvarnost. Njihovo će posvećenje postati savršeno nakon uskrsnuća iz mrtvih, odnosno, na Kristov Dan. Pavao opisuje taj dan u Filipljanima 3,20-21, kada će Gospodin „prema djelotvornosti kojom može sve podložiti sebi, preobraziti naše bijedno tijelo i učiniti ga jednakim svome slavnom tijelu“.

\section{Posvećenje kroz oponašanje pobožnih primjera}

Do sada smo razmatrali tu okomitu dimenziju vjernikove preobrazbe u Kristovu sliku. Preobražavamo se u sliku koju zapažamo kroz Riječ i Duha, zajedno s Pavlom težimo tomu da spoznamo, dobijemo i budemo pronađeni u Kristu (Fil 3,8-9). Međutim, postoji još jedna važna i često zanemarivana dimenzija preobrazbe u Kristovu sliku, ona vodoravna. Kao što je jedan autor napisao: „Kako oni koji vjeruju u Krista mogu slijediti čovjeka kojeg nikada nisu upoznali?“ (Reeves 2011,243). Pavao i drugi apostoli bili su svjesni toga problema, a gornjoj okomitoj dualnosti Riječi i Duha, kao sredstava te preobrazbe u sliku Kristovu, često su dodavali vodoravnu dimenziju: oponašanje!

\section{Poziv na oponašanje}

Biblija nas potiče da oponašamo ili nasljedujemo Krista. Krist je svoje učenike pozvao da uče od Njega (Mt 11,28-30). Prvi su kršćani prije svega bili nazivani učenicima, a dužnost je učenika da „vrše sve što sam vam zapovjedio“ (Mt 28,20), ali i da idu "njegovim stopama“ (1 Pt 2,21). Gospodin Isus je uputio poziv na oponašanje kada je doslovno pozvao učenike da ga slijede, da hodaju „njegovim stopama" (1 Pt 2,21) po prašnjavim cestama Galileje, Samarije i Judeje, promatrajući Njegov primjer. Zanimljivo je da se za život vjere često koristi grčka riječ koja doslovno znači hodati $(\pi \varepsilon \rho \iota \pi \alpha \tau \dot{\varepsilon} \omega)$. Taj poziv na oponašanje i nasljedovanje neodvojivo je vezan uz učeništvo. ${ }^{27}$ Poslanica Filipljanima svakako nas poziva da slijedimo Kristov primjer (Fil 2,5). Međutim, kada govorimo o oponašanju

27 Zahvalan sam Ervinu Budiseliću, koji mi je na to ukazao u svome osvrtu na prvi nacrt ovoga članka. 
Krista, možemo upasti u zamku razmišljajući o Kristu samo kao o Božjem čovjeku čiji smo moralni primjer sposobni slijediti sami od sebe. Alister McGrath nas upozorava na takvo izvanjsko oponašanje: „Ovaj oblik egzemplarizma poziva nas da vjerujemo u Isusa Krista kao primjer koji nam pokazuje, kao onoga koji je izvan nas i povijesno udaljen od nas, što bismo trebali učiniti. Međutim, nemoćan je preobraziti tragičnu stvarnost čovječanstva kako bi se to moglo postićí (McGrath 1991, 292).

Drugim riječima, naš nauk o oponašanju Krista uvelike ovisi i trebao bi biti svjesno vezan uz naš nauk o posvećenju. Oponašanje Krista ne sadrži se toliko od razmišljanja Što bi Isus učinio u određenoj situaciji, nego od rasta u pravoj i sveobuhvatnoj spoznaji Isusa Krista, koja se očituje u Njegovim stavovima, a koje Pavao u Galaćanima 5,22 naziva plodom Duha.

\section{Oponašanje Krista (Fil 2,5)}

Jedini Pavlov izravni poticaj na oponašanje Krista istovremeno potvrđuje i informira takvo gledište o posvećenju kao preobrazbi u Kristovu sliku. Doslovni prijevod ovoga stiha glasio bi: „Ovo mislite u sebi što i u Kristu Isusu.“ Očigledan nedostatak drugoga glagola iznjedrio je različita tumačenja ovoga stiha. Martin: „Imajte ovo mišljenje među vama dok razmišljate u Isusu Kristu, tj. kao članovi Njegove crkve" (Martin 1991, 75-76). ${ }^{28}$ Međutim, J. B. Lightfoot daje bolje tumačenje: „Neka vaši umovi odražavaju um Krista Isusa. Budite ponizni kao što je i On bio ponizan“ (Lightfoot 1981, 110; v. Hendriksen 1964, 102; O’Brien 1991, 205.).

Glagol фрovéw u ovomu kontekstu znači „,imati misli ili stav(ove), biti sklon ili težiti“ (Bauer, Arndt and Gingrich 1957, 874), a prezent „podrazumijeva kontinuiran, uobičajen stav“ (Rogers Jr. i Rogers III 1998, 451). Prema tomu, dobar prijevod bi glasio: „Neka ovaj stav bude u vama, kao što je bio i u Kristu Isusu”. To nam pomaže da zadržimo funkciju ovoga stiha kao zglob koji povezuje pozive na poniznost, traženje koristi jedni drugih, ljubav i jedinstvo (Fil 2,1-4) s Kristovim uzvišenim stavom poniznosti i poslušnosti $(2,5-11) .{ }^{29} \mathrm{Zbilja}$, svi poticaji

koje svoga Oca i Njegovih izabranika. Krist je volio ovaj svijet istom ljubavlju koju je i Otac imao (Iv 3,16), tako da je dao svoj život kao otkupninu. Krist se borio za „vjeru Radosne vijesti“ (Fil $1,28)$, čvrsto držeći riječ života $(2,16)$. Konačno, apostol poziva Filipljane da se prilagode Kristovoj slici, čak i u pogledu njegova uzvišenja. Njegovo uzvišenje uskrsnućem nije samo osiguralo njihovo uskrsnuće u slavu nego istovremeno trebamo oponašati Kristov stav podložnosti Bogu Ocu da ga uzvisi u pravo vrijeme. Filipljani su pozvani da oponašaju taj stav prije svega tako što se neće tjeskobno brinuti ni za što, nego će svoje potrebe izreći Bogu kroz molitvu $(4,6$; ali vidi povezanost bacanja brige na Boga i uzvišenja u svoje vrijeme u 1 Pt 5,6-7). 
na posvećenje u ovoj Poslanici na različite načine pronalaze svoje nadahnuće u Kristovu primjeru u Fil 2,5-11. Ponovno, Kristov primjer vjernicima ne služi kao neka ilustracija koju bi trebali mehanički oponašati. Bog je taj koji će usavršiti to „dobro djelo“ preobrazbe u Kristovu sliku do Njegova povratka (Fil 1,6). Duh Isusa Krista daje Pavlu svu potrebnu pomoć u njegovim okovima $(1,19)$, tako da može učiniti sve u Bogu koji mu daje snagu $(4,13) \cdot{ }^{30}$ Bog je proizvodi i htijenje i djelovanje u Filipljanima $(2,13)$. U konačnici, Božji narod čine oni koji se posvećuju uz poticaj i u snazi Duha Božjega te koji se ne pouzdaju u vlastite prirodne sposobnosti $(3,3)$.

Dakle, posvećenje, koje apostol opisuje kao oponašanje Kristova primjera i prilagođavanje kroz spoznaju Krista ${ }^{31}$, nije neko legalističko izvršavanje izvanjskih zakona, nego preobrazba u Kristovu sliku u sili Svetoga Duha. ${ }^{32}$

\section{Oponašanje apostola Pavla (Fil 3,17a i 4,9)}

Cijela je poslanica Filipljanima bogata Pavlovim primjerom života u Kristu. Premda je Krist, kako ga Zemek naziva, prauzor i najveći primjer, drugim riječima, naš par excellence primjer, koji „jedini odražava tu savršenu Božju moralnu sliku“" (Zemek 2002, 264), Pavao koristi više prostora u Poslanici da nam pokaže vlastiti primjer. Stoga, ne čudi nas kada poziva vjernike, kao što to čini u svojim drugim poslanicama, da ga oponašaju u 3,17a: „Zajedno nastavite biti moji oponašatelji..." (autorov prijevod). Apostol koristi imenicu $\sigma \cup \mu \mu \iota \eta \eta \tau \dot{s} \mathrm{u}$

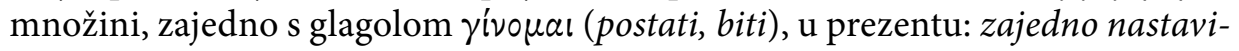
te biti oponašatelji. Budući da je glagol u prezentu, odražava kontinuiranu radnju. Prefiks ov- označava da su Filipljani to trebali činiti skupa, kao zajednica, što bi zasigurno pomoglo njihovu jedinstvu. ,Mimeimai ima smisao 'oponašati', 'imitirati', odnosno, činiti ono što vidimo da netko drugi čini“" (Zemek 2002, 254).

Kroz svoj primjer širenja evanđelja, dok je bio u zatvoru, apostol je pogana ohrabrio „većinu braće“ da budu još više „ohrabrena u Gospodinu... bez straha

30 Ovdje u Fil 1,6 i u 2,13 Pavao koristi participe da bi opisao Boga: Onaj koji je započeo, Onaj koji proizvodi u vama te Onaj koji osnažuje. Svi ti participi postaju osobne imenice za Boga i otkrivaju nam nešto o Božjoj naravi u pogledu kršćanskog života i posvećenja.

31 Vidi 1 Iv 3,2, gdje apostol Ivan opisuje proslavljenje kao trenutak kad ćemo biti poput Isusa, jer ćemo ga vidjeti onakvoga kakav jest. Drugim riječima, tada će naša spoznaja postati potpuna i tada će naš Gospodin, da posudimo izraz iz Fil 3,21, preobraziti tijelo naše poniznosti u skladu sa svojim slavnim tijelom.

32 Kristov primjer unutarnjih stavova stoga postaje vjerniku ono što Pavao na drugome mjestu naziva „Kristov zakon“ (vidi 1 Kor 9,21, a posebno Gal 6,2, gdje Pavao kaže da ćemo ispuniti Kristov zakon kada nosimo bremena jedni drugih). William Hendriksen (1990, 233) piše: „Taj je Kristov zakon načelo ljubavi jednih prema drugima koju nam je dao Krist... Međutim, Krist nije samo objavio taj zakon; on je bio i njegov primjer." 
propovijedati riječ Božju“ $(1,14)$. On prije svega živi za Krista $(1,21)$, za Njegovu slavu $(1,20)$, a njegov život treba donijeti plod - rad $(1,22)$ i napredak vjere Filipljana (1,24-25). Pavao nikad ne potiče svoju duhovnu djecu da ga slijede putem kojim on sam već nije hodao. Ohrabruje ih da uvijek budu radosni unatoč brigama i problemima $(2,18 ; 3,1 ; 4,4)$, međutim, zatočen u Rimu u iščekivanju suđenja, ovaj Kristov sluga također se raduje! Raduje se kada se propovijeda Krist $(1,18)$ pa čak i kada to poveća bol njegovih okova; jedinstvo, ljubav i poniznost Filipljana donose mu radost $(2,2)$ te radosno iščekuje zajedništvo koje će ponovno uživati s njima $(2,18)$. Zbilja, oni su njegova "radost“ $(4,1)$. Pavao se također raduje zato što je primio poklon od Filipljana $(4,10)$, ali ne raduje se toliko $\mathrm{u}$ poklonu, koliko u činjenici da su ga se sjetili i da su time dobili za sebe duhovnu korist (Fil 4,17).

Pavao ujedno služi i kao primjer borbe za vjeru Radosne vijesti (1,30, usp. 1,27) koju su Filipljani trebali oponašati. Požrtvovno ih voli i stavlja njihovu korist ispred vlastite (2,17-18, usp. 2,4). Nadalje, primjer je ispravnog razmišljanja o posvećenju (3,2-15), kada iz vlastitog iskustva i primjera izvlači pouku da vjernici ne mogu postići bezgrešno savršenstvo s ove strane paruzije. Za razliku od Krista, Pavao nije primjer moralnog savršenstva, nego primjer vjernika koji, kroz Božju snagu, ${ }^{33}$ teži biti sličniji Kristu $(3,12-14) .{ }^{34} \mathrm{U}$ Filipljanima 4,9, vidimo još jedan imperativ koji Pavao koristi da pozove vjernike da ga oponašaju: „Ono što ste od mene naučili i primili, što ste od mene čuli i na meni vidjeli, to nastavite činiti, pa će Bog, izvor mira, biti s vama." Filipljani su trebali oponašati Pavlovo učenje (naučili i primili) i njegovo ponašanje (od mene čuli i na meni vidjeli), i zbog toga, Bog mira bit će s njima. Ovo dolazi nakon dobro poznatoga odlomka, gdje ih uči da se ne brinu tjeskobno ni za što, nego da sve svoje brige predaju Bogu, čiji će mir zatim čuvati njihova srca i njihove misli u Kristu. Taj isti rezultat također dolazi od oponašanja Pavlova učenja i života (redak 9). Stoga, zapažamo da je apostol bio živi primjer takvoga pouzdanja u Krista. On im ne obećava da će Bog mira biti s njima zato što slijede njegov primjer, nego zato što u oponašanju njegova primjera (i učenja), slijede Krista (usp. Fil 2,5 s 2,1 i 4,8).

Pavao je očekivao da će njegovi čitatelji slijediti njegov primjer; taj model života i službe koji su mogli promatrati dok je bio s njima, o kojem su čak i sada mogli čuti $(1,30)$. Očekivao je da će oni slijediti njega kao što on slijedi Krista (1

33 Međutim, usp. Hebr 5,8-9, gdje je čak i Krist kao čovjek trebao iskustveno naučiti poslušnost. Naravno, to nipošto ne znači da je ikad sagriješio.

34 Vidi zadivljujuće sličnu ideju u 1 Kor 10,32-11,1, gdje Pavao kršćane poziva da nikoga ne sablazne i navodi vlastiti primjer požrtvovne ljubavi prema drugima u tome što ne traži vlastitu korist, nego korist drugih u želji da se spase. Nakon toga, poziva ih da ga oponašaju, kao što i on oponaša Krista. 
Kor 11,1). Njegov primjer prije svega se odnosi na stavove koji su usmjeravali njegov život i njegovu službu, dok je istovremeno obuhvaćao i njegovo ponašanje.

\section{Oponašanje vjernih oponašatelja (Fil 3,17b)}

Kada je Gospodin Isus svojim učenicima u Mateju 7,16 rekao da će lažne učitelje prepoznati „po njihovim plodovima“, izrekao je nedvosmislenu istinu da možemo prepoznati lažne (kao i istinske) vjernike i propovjednike po načinu na koji žive. „Tako svako dobro stablo rađa dobrim rodom, a zlo stablo rađa zlim rodom“ (Mt 7,17). Loši su plodovi proizvod lošega stabla. Kao što vjernici trebaju prepoznati i kloniti se lažnih proroka, trebaju zapaziti i prepoznati i dobre primjere vjernosti u njihovoj lokalnoj crkvi, kao i u crkvi općenito (na primjer, čitajući biografije muškaraca i žena vjere). Nakon što je Filipljanima dao pobudu da oponašaju njegov primjer, apostol je usmjerio njihovu pažnju na one koji „žive prema primjeru što vam ga mi dajemo" (Fil 3,17$)$. Već sam spomenuo mogućnost da su među njima bili i nadglednici i đakoni koje Pavao spominje u pozdravu $(1,1)$. Moguće je da je jedan od tih nadglednika trebao pomoći Evodiji i Sintihi da budu jedinstvene.

Vjernici u Filipima trebali su među sobom tražiti zrele kršćane (Fil 3,15), koji su slijedili Pavlov primjer. ${ }^{35}$ Trebali su pažljivo promatrati i oponašati njihov primjer. ${ }^{36}$ Među takvima je bio i Timotej, kojega im se Pavao nadao poslati, vidi 2,19), kao i Epafrodit.

Timotej (Fil 2,19-23) je prikazan kao primjer vjernika koji iskreno brine za Filipljane, netko tko ne traži vlastitu korist, nego korist Isusa Krista (redak 21, usp. Fil 2,4). Isus koristi istu riječ za tjeskobnu brigu u Matejevu evanđelju 6,31-34, a Pavao je također koristi kasnije u Filipljanima 4,6. Timotej se jednako intenzivno brinuo o Filipljanima kao što se neki ljudi pogrešno brinu o vlastitim potrebama. Također, služio je Radosnu vijest (redak 22, usp. Fil 1,27; 2,16) pomažući Pavlu kao što sin pomaže svome ocu. Epafrodita (Fil 2,25-30) su Filipljani poslali da pomogne Pavlu u zatvoru, no jako se razbolio (redak 27) i našao se blizu smrti radi Kristova djela (redak 30, usp. Fil 1,20; 2,17). Pavao poziva Filipljane da ga prime radosno i da poštuju takve ljude. Pavao vjerojatno misli i na njega kada ih poziva da promatraju one koji žive prema primjeru koji im je ostavio. ${ }^{37}$

35 BAG 1957, 837-838: „preslika, slika, oblik, figura, obrazac, (arhi)tip, obrazac, model, u moralnom životu primjer, obrazac, o tipovima koje Bog daje kao one koji ukazuju na budućnost, u obliku osoba ili stvari.“

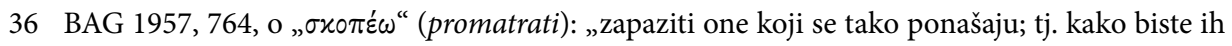
ponašali“. To je zapažanje koje zahtijeva prikladno djelovanje. Usp. Rim 16,17; Gal 6,1.

37 Ako se množina, nas, u Filipljanima 3,17 odnosi na apostola i njegove suradnike, moguće je da Epafrodit stoji zajedno s Pavlom i Timotejem kao primjer kršćanskog života koji drugi trebaju nasljedovati. 
U zaključku, u Poslanici Filipljanima nalazimo poziv da oponašamo Gospodina Isusa kao vrhovni primjer poniznosti, požrtvovne ljubavi, poslušnosti i svih ostalih vrlina koje je apostol pozvao svoje čitatelje da oponašaju. Premda Pavao nije to izrazio tako jasno kao u 1. Korinćanima 11,1, Poslanica Filipljanima jasno implicira da je Pavao svoju duhovnu djecu pozivao da oponašaju njega, baš kao što je i on oponašao Kristov primjer. Pozivao ih je da njeguju te unutarnje stavove poniznosti, podložnosti i požrtvovne ljubavi koje je i on sam oponašao promatrajući Krista. Na kraju, potaknuo ih je da promatraju živote onih koji su živjeli prema primjeru koji su ostavili on i njegovi suradnici.

\section{Zaključak}

U svojoj satiričkoj pjesmi I Want To Be A Clone (Želim biti klon), Steve Taylor izrugivao se legalističkim crkvama koje su od svojih članova tražile potpunu uniformnost, koje su uskogrudne i netolerantne prema bilo čemu što se razlikuje od njihova zamišljenoga kršćanskog standarda: „Budi klon i zaboravi na svoja uvjerenja / kloniranju je mjesto uz pobožnost, zar ne? / Zahvalan sam što su mi pokazali put / Jer nikada ne bih znao / Služiti mu sam / Želim biti klon“" (Taylor 1983).

Premda se slažem s Taylorovim sentimentima, Biblija nas ipak poziva na određenu vrstu kloniranja, na oponašanje kristoličnih stavova i ponašanja koje vidimo u drugima. Biblijski naglasak na prebivanju Svetoga Duha u svakom vjerniku i na Njegovo prosvjetljivanje njihova uma da razumiju istine koje su nevjernicima zamračene (1 Kor 2,10-16) ponekad se mogu zlouporabiti u pretjeranom individualizmu i samopouzdanju, zajedno s nepovjerenjem i cinizmom prema crkvi kao ustanovi. Kada vidimo sve to licemjerje i sve neuspjehe Crkve da živi u skladu sa svojim pozivom, možemo početi izbjegavati oponašanje bilo koje vrste - pa čak i izbjegavati crkvu (Keyes 2006, 202). Zatim možemo pokušati pronaći vrstu duhovnosti koja će uvijek biti svježa, duhovnosti popraćenu mentalitetom ja i moja Biblija - $i$ više nitko ili pak ja i moj propovjednik s YouTubea. Međutim, problem je u tome što mi tako ne osiromašujemo samo sebe pobožnih primjera drugih vjernika, koji se bore i teže oponašati Krista, nego dokidamo druge našega primjera borbe i stremljenja prema većoj sličnosti s Kristom!

Krist nas ne poziva da budemo klonovi. Čak i među Dvanaestoricom možemo zapaziti veliku raznolikost u pogledu osobnosti. Ipak, možemo isto tako vidjeti da su oponašali Krista u Njegovim stavovima, ljubaznosti, poniznosti i ljubavi. (Na primjer, usp. Fil 2,5-11 s 1 Pt 2,21-25) Zemek umješno izražava ovu sintezu posvećenja i oponašanja:

„Prvenstveno sredstvo milosti u pokretanju spašenih na njihovu putu posvećenja je Božja riječ koju potvrđuje Duh Božji, a bitan dio toga božanskog svjedočanstva jest utjelovljeni primjer Kristov. Zbilja, On ostaje kao Božje sa- 
vršeno moralno očitovanje. ... Zbog Kristova primjera, stavovi i djela Njegova naroda sazrijevat će u integritetu i dosljednosti prema sličnosti s Kristom (vidi Fil 1,27 $i$ dalje; 1 Iv 2,6). Dok budu moralno sazrijevali, neki će sazrjeti brže od drugih, tako da će i oni sami postati odrazi Njegova moralna primjera (usp. 1 Sol 1,7)“ (Zemek 2002, 252).

U praksi, takvo oponašanje moralnih primjera obuhvaća i razmišljanje i stavove (Fil 2,5; 3,15), kao i ponašanje (Fil 3,17). Izvan Poslanice Filipljanima, Pavao potiče Timoteja da bude uzor vjernicima „u riječi, u vladanju, u ljubavi, u vjeri, u čistoći“ (1 Tim 4,12). Svu ozbiljnost toga poticaja možemo razumjeti ako pročitamo nekoliko redaka kasnije, gdje mu je njegov duhovni otac napisao: „Pazi na samog sebe i na nauku! Ustraj u ovim dužnostima, jer radeći ovo spasit ćeš i samoga sebe i svoje slušatelje!“ (1 Tim 4,16). Njegovo ponašanje ne može samo lišiti njegovo propovijedanje sile, nego može postaviti loš primjer koji bi donio skandal i odveo na stranputicu one koji su slabi i u neznanju. Pavao je pokazao da zreli, primjerni vjernici nipošto ne misle da su postigli neku vrstu savršenstva. Zreli vjernici trebaju to nekako prenijeti onima koji na njih gledaju kao na uzore. Oponašatelji trebaju oponašati čak i način na koji oni ustaju poslije pada, kao i poniznost kada su ukoreni te njihovu spremnost na pokajanje i promjenu. ${ }^{38} \mathrm{Ta}-$ kva misija daje novu ozbiljnost i njeguje osjećaj osobne nedostatnosti i poniznosti u svima koji služe kao duhovni vođe u crkvi. Naš primjer može spasiti mnoge, ali može ih i osujetiti, pa čak i uništiti. Neka nam Gospodin bude milostiv te nam po Svetom Duhu i kroz svoju Riječ pruži Kristov primjer i primjeran život onih na čijim ramenima stojimo, da se svakodnevno „preobražavamo $u$ tu istu sliku, uvijek sve slavniju“ (2 Kor 3,18).

Prema tomu, u našem razmatranju nekih relevantnih odlomaka u Poslanici Filipljanima, uočili smo Pavlovu teologiju posvećenja. Vidjeli smo da Bog obećava dovršiti dobro djelo koje je započeo u nama, da je Bog začetnik i ostvaritelj našeg posvećenja. Bog želi da rastemo u spoznaji Krista jer, bez spoznaje Kristove

38 U posljednjih nekoliko desetljeća misiolozi su postali svjesni opasnosti kršćanske hagiografije, odnosno „biografskih izvještaja koji misionara predstavljaju kao osobu koja praktično radi greške; osobu koja se odrekla osobnih želja, ambicija, obitelji, prijatelja i sigurnosti; čije su prosudbe uvijek dobre; čiji je integritet nepobitan; te čije je ponašanje bilo uvijek dosljedno kristolično" (Neely 1999, 443). Problem s ovim izvještajima nije samo u tome što su lažni i što gotovo uvijek remete proučavanje misiologije nego što su potpuno beskorisni za oponašanje. Teško je poistovjetiti se s duhovnim super-herojem, koji uvijek uspije u svemu što radi. S druge strane, Biblija je protuhagiografska. Pokazuje nam neuspjehe i vođa i kršćana općenito, poput Mojsijeva ubojstva, Davidova preljuba, Petrova nijekanja Krista i Pavlova nestrpljenja s Markom. Međutim, pokazuje nam i Mojsijevu slomljenost, Davidovo pokajanje, Petrovu hrabrost i Pavlovu kasniju afirmaciju Marka i ljubav prema njemu. Razlog tomu je, pretpostavljam, taj što nam ne trebaju samo primjeri uspjeha, nego i primjeri vjernika od krvi i mesa, koji su se Božjom milošću uspjeli povratiti nakon neuspjeha. 
osobe i djela, ne možemo rasti u sličnosti s Kristom, koja je cilj kršćanskog života. Nakon toga, vidjeli smo da je taj rast u sličnosti s Kristom neodvojivo vezan uz oponašanje Njegova primjera, prije svega Njegovih stavova, ali i Njegova ponašanja. Nadalje, nasljedovanje Krista podrazumijeva oponašanje stavova i prakse Pavla i onih vjernika koji oponašaju Pavla. Trebamo postati njihovi oponašatelji, ali i uzori koje će drugi moći oponašati kao vodoravnu dimenziju vjernikove preobrazbe u sličnost s Kristom.

\section{Literatura}

Allison, Gregg, and Chris Castaldo. 2016. The Unfinished Reformation: What Unites and Divides Catholics and Protestants After 500 Years. Grand Rapids. Zondervan.

Bauer, Walter, William F. Arndt, and F. Wilbur Gingrich. 1957. A Greek-English Lexicon of the New Testament and Other Early Christian Literature. Chicago. The University of Chicago Press.

Calvin, John, Pringle, John. 2010. Commentaries on the Epistles of Paul the Apostle to the Philippians, Colossians, and Thessalonians. Bellingham. Logos Bible Software.

Crotts, John. 2018. Graciousness: Tempering Truth with Love. Grand Rapids. Reformation Heritage Books.

Foulkes, Francis. 1994. Philippians. U: D.A. et al. New Bible Commentary: 21st Century Edition. Leicester. England; Downers Grove. Inter-Varsity Press.

Hendriksen, William. 1990. New Testament Commentary: Galatians \& Ephesians. Edinburg. The Banner of Truth Trust.

Hendriksen, William. 1964. New Testament Commentary: Philippians, Colossians and Philemon. Grand Rapids. Baker Book House.

Jamieson, Robert, A. R. Fausset, and David Brown. 1997. Commentary Critical and Explanatory on the Whole Bible, vol. 2. Oak Harbor. Logos Research Systems, Inc.

Keener, Craig S. 2009. The Gospel of Matthew: A Socio-Rhetorical Commentary. Grand Rapids i Cambridge. Eerdmans.

Keyes, Dick. 2006. Seeing Through Cynicism: A Reconsideration of the Power of Suspicion. Downers Grove. InterVarsity Press.

Lightfoot, J. B. 1981. St. Paul's Epistle to the Philippians. Lynn. Hendrickson Publishers.

Lincoln, Andrew T. 1990. Word Biblical Commentary: Ephesians. Dallas. Word Books. 
Martin, Ralph. 1991. Tumačenje Pavlove poslanice Filipljanima: Uvod i komentar (Original: Tyndale New Testament Commentaries Philippians - An Introduction and Commentary. Novi Sad. Dobra Vest.

McGrath, Alister E. 1991. In What Way Can Jesus Be A Moral Example For Christians? Journal of Evangelical Theological Society 34/September. 289298.

Moo, Douglas. 1996. The New International Commentary on the New Testament: The Epistle to the Romans. Grand Rapids. Eerdmans.

Neely, Allan. 1999. Saints Who Sometimes Were: Utilizing Missionary Hagiography. Missiology: An International Review 27/4. 441-457.

O’Brien, Peter T. 1991. The New International Greek Testament Commentary, NIGTC, The Epistle to the Philippians. Grand Rapids. Eerdsmans i Paternoster Press.

Reeves, Rodney. 2011. Spirituality According to Paul: Imitating the Apostle of Christ. Downers Grove. IVP Academic.

Rogers Jr., Cleon L., and Cleon L. Rogers III. 1998. The New Linguistic and Exegetical Key to the Greek New Testament. Grand Rapids. Zondervan.

Schreiner, Thomas R. 2008. New Testament Theology: Magnifying God in Christ. Grand Rapids. Baker Academic.

Schreiner, Thomas R. 2001. Paul: Apostle of God's Glory in Christ. Downers Grove i Leicester. IVP Academic.

Spurgeon, Charles, and Elliot Ed. Ritzema. 2014. Spurgeon Commentary: Philippians. Bellingham. Lexham Press.

Swanson, James. Dictionary of Biblical Languages with Semantic Domains: Greek. Bellingham WA: Logos Research Systems, 1997.

Wallace, Daniel B. 1996. Greek Grammar: Beyond the Basics. Grand Rapids. Zondervan.

Welch, Edward T. 1997. When People Are Big and God Is Small: Overcoming Peer Pressure, Codependency and the Fear of Man. Phillipsburg. P\&R Publishing.

Witherington III, Ben. 2011. Paul's Letter to the Philippians: A Socio-Rhetorical Commentary. Grand Rapids i Cambridge. Eerdmans.

Wuest, Kenneth S. 1997. Wuest's Word Studies from the Greek New Testament: For the English Reader. Grand Rapids. Eerdmans.

Zemek, George J. 2002. The Modeling of Ministers. U: Richard L. Mayhue, \& Robert L. Thomas. The Master's Perspective on Pastoral Ministry. Grand Rapids. Kregel Publications. 
Miroslav Balint-Feudvarski

\title{
Sanctification Through Knowledge and Imitation in Philippians
}

\begin{abstract}
Throughout the New Testament, we find exhortations to imitate or follow in the steps of Christ, Paul and even some other godly people. In the Epistle to the Philippians, we find this exhortation to imitate incorporated into a Pauline theology of progressive sanctification. Sanctification in Philippians is portrayed as a conforming to Christ through the knowledge of Him, which comes through tripartite means of the Word of God (the Apostolic teaching), the internal work of God's Spirit and the imitation of Christ, the Apostle Paul and other godly examples. We will aim at forming a biblical theology of sanctification through imitation restricted in our analysis to the Epistle of Philippians. First part of the article reviews the teaching of sanctification in Philippians, with an emphasis on passages where Paul directly addresses this issue: Philippians 1:9-11, 27-29; 2:12-16; 3:1-15. Second part of the article introduces us to biblical teaching on imitation, and then it reviews a downward spiral of imitation: imitating Christ (Phil. 2:5), imitating Paul (Phil. 3:17a; 4:9) and imitating Paul's faithful imitators (Phil. 3:17b). In the conclusion, we will see that imitation of Christ and His faithful imitators is a means of progressive sanctification that is both important and often neglected, both by those who should serve as primary examples of godliness (spiritual leaders) and those who need to learn by imitating.
\end{abstract}

Key terms: imitation, sanctification knowledge, transformation, model, Christ, Paul, Philippians, Holy Spirit, Scriptures 